\title{
Perceptions of Legal Aspects of Price Tagging of Balinese Betutu Chicken
}

\author{
Simon Nahak ${ }^{1}$, Agus Darma Yoga ${ }^{2}$, \& Mirsa Umiyati ${ }^{3 *}$ \\ ${ }^{1}$ Program Studi Magister IImu Hukum, Universitas Warmadewa \\ 2,3Program Studi Magister IImu Linguistik, Universitas Warmadewa \\ *Email: mirsa.umiyati2@gmail.com
}

How to cite (in APA style):
$\begin{aligned} & \text { Nahak, S., Yoga, A. D., Umiyati, M. (2021). Perceptions of Legal Aspects of Price Tagging of Balinese Betutu Chicken. } \\ & \text { Jurnal Hukum Prasada, 8(1), 1-7. doi: https://10.22225/jhp.8.1.2943.56-64 }\end{aligned}$

\begin{abstract}
This study aims to determine community perceptions about the legal aspects of price tagging in Balinese chicken Betutu sales. The population of this study was housewives in Banjar Anyar, Sumertha Kelod Village, East Denpasar District, Denpasar, Bali. This study used a survey sample (cross sectional study). The variables of this study are: (1) The importance of giving price tags; (2) Without the label violating the law; (3) The constitution on the sale of goods. Based on the analysis, the results of this study indicate that as much as $65 \%$ of respondents consider the price tagging important in sales and $3.9 \%$ of the 103 respondents consider that the price tagging in selling Balinese chicken Betutu is less important. Meanwhile, at the level of understanding without labels violating the law, $55.3 \%$ of respondents did not know that without a label in selling Balinese chicken betutu was against the law and only $14.6 \%$ of respondents knew that without a label in selling Balinese chicken Betutu was against the law. At the level of understanding of the laws on the sale of goods, $77.7 \%$ of respondents did not know about the laws on selling goods and only $4.9 \%$ of respondents knew about the laws on selling goods. Based on these results it can be concluded that there are still many people who do not know the importance of labeling a business product and the legal aspects of labeling a business product.
\end{abstract}

Keywords: Chicken Betutu; Constitution; Law Violation; Public Perception; Price Tags

\section{INTRODUCTION}

Food is a primary need that must be met apart from other secondary needs. In addition, food is not only consumed for personal needs but also for sale. What is meant in this case is the effort made by some people to meet the needs of others in order to gain profit or income. Due to advances in technology today, sellers have two ways to trade their businesses or products. There are those who sell it directly, in this case the seller has a place to eat to buy and sell their trade, but there are also sellers who take advantage of technology by selling their wares via the internet or currently known as e-commerce. This is done because it is felt that e-commerse-based information can increase competitive advantage, among others, to meet consumer needs quickly because buyers deal directly with sellers without intermediaries, availability of accurate product information, expand geographic reach, increase sales of goods/products, and convenience in transactions without the need to come to the point of sale as sufficient to view the information on the website and click on the desired item/product (Nugraha, 2014).

In the process of selling traded products, of course, strategic information is needed to facilitate the flow of the said buying and selling. This information includes the availability of goods or services needed by the consumer community, about product quality, safety, prices, on various requirements and/or how to obtain them, about product warranties or guarantees, 
spare parts inventory, the availability of full-sale services, and others. others related to it, (Kristiyanti, 2008:70). Among the various information about consumer goods or services needed by consumers, it seems that the most influential at this time is information sourced from business actors. Especially in the form of advertisements and labels, without reducing the influence of various other forms of entrepreneurial information (Kristiyanti, 2008:71). This mandatory consumer product information is stipulated in various laws and regulations. Arrangement of information referred to by terms such as markings, labels or tags. These provisions are contained in various laws and regulations (Kristiyanti, 2008:71). Alfian \& Marpaung (2017) in their research say that there is a significant indirect effect of label and brand image variables on purchasing decisions through price. The results of this study were also supported by Rosidi et al. (2018) that there is a relationship between food knowledge and product purchasing decisions. From a legal aspect, buyers / consumers have protection in the form of laws that have been regulated in Law No. 8 of 1999 concerning Consumer Protection.

Regarding the labeling of prices in food (food) it is necessary to pay attention to it because all types of food and beverages that are marketed have been regulated in law, including Law no. 7 of 1996 concerning Food, PP. 69 of 1999 concerning Food Labels and Advertisements, Permendag No.22 / M-DAG / PER / 5/2010 concerning the Obligation to Include Labels on Goods, Law No. 36 of 2009 concerning Health, Regulation of the Minister of Health of the Republic of Indonesia No. 180 / Menkes / Per / IV / 1985 concerning Expired Food which has been amended by the Decree of the Director General of POM No. 02591 / B / SK / VIII / 91. UU no. 8 of 1999 concerning consumer protection as an umbrella law does not specifically regulate labeling, especially food products, including labeling of food products.

Betutu chicken, as one of the Balinese specialties sold in stalls generally does not have a price tag. The price tag is not included on the chicken betutu menu because not all sellers consider food labeling important and also do not know that there is a law regulating price labeling on food. In addition, housewives' knowledge of the labeling regulations for food packaging is categorized as still lacking, especially knowledge of the definition of labels and the function of labels on food packaging (Septian \& Rahayu, 2014). Devi et al. (2013) said that there is a strong positive relationship between the level of respondents' knowledge about food labels. In fact, in terms of benefits and in accordance with applicable laws, the purpose of labeling is to provide correct and clear information to the public regarding each packaged processed food product before buying and / or consuming processed food. In addition Arifiana et al. (2013) also stated that the factors of price, brand, packaging, quality, labels can influence consumers in making purchasing decisions.

The fact that happens about labeling is the number of sellers who do not put labels on the products, goods or services being traded. This is because producers are more oriented to get the maximum profit with the smallest possible expenditure, while the inclusion of labels, producers have to pay large costs to make labels on products, goods or services (Iskandar, 2015). Basically, this labeling is very much considered in the decision to buy an item or product by consumers. For consumers, labels have a very important role, at least there are three basic things that underlie it, namely: 1. Information needed as a consideration for buying or not certain products; 2 . With this knowledge, consumers can determine, choose one product over other similar products; 3 . With correct and complete information, consumers can also avoid the possibility of interference with the safety and security of their consumption, if the production concerned is not suitable for themselves or contains a substance that is harmful.

In general, labels on products, goods or services themselves have a purpose and function for their use, namely to provide information for the benefit of consumers. Another purpose of labeling in a product apart from providing information about the contents of the labeled product without having to open the packaging, also serves as a means of communication between producers and consumers about things that consumers need to know about the product, especially things that are visible or physically unknown. Labeling also provides the right instructions for consumers to obtain optimum product function. A 
means of advertising for producers and providing a "sense of security" for consumers. Labels on product packaging are not only used as decoration, but also to assist consumers in deciding whether to purchase the food product or not. In fact, the sale of a product, goods and services by a seller who does not use the label smoothly, there is no objection to the labeling of either the buyer or the seller. The understanding of this labeling is very complex, so it needs a study in the form of research.

There are several studies that have been done regarding labeling. Elisabeth (2017), for example, examines the effect of packaging and labeling on the acceptance of dry noodles. This study used 32 respondents. The results of this study indicate that the respondents' acceptance of the packaging and labeling of dry noodle products made from taro and sweet potato flour is still low. Respondents found that some information such as expiration date and net weight of the product was still unclear. This causes respondents to be not interested in buying these products, apart from the reasons for the high price of the product and the low attractiveness of the product. A similar study was also investigated by Puasa (2017), which examined the regulation of food labels and advertisements and legal liability for food labels and advertisements. The results of this study indicate that 1) Food labels and food advertisements are information or statements on food packaging aimed at informing something about the condition and quality and as promotional materials to attract consumer interest. 2) Violation of food labels and food advertisements results in both civil and criminal liability as a form of legal application, and law enforcement through product liability is only borne by business actors or corporations that produce and or distribute the food. Maharani \& Markeling (2018) in the study also examined things that were similar to the current research, namely the legal consequences of differences in the price of goods on the label (price tag) and the cashier price. The results of this study indicate that if referring to Law Number 8 of 1999, if a difference in price is found on the label (price tag) and the cashier's price, the business actor is proven to have violated Article 8 paragraph (1) letter $f$ of Law Number 8 of 1999 concerning Protection. Consumers and can be subject to sanctions in the form of imprisonment and fines. Consumers are expected to be more careful when looking at the price on the label (price tag) and when making payments on checkout. Meanwhile, business actors do not seek solely profit but also prioritize consumer satisfaction. Based on the results of several studies that have been described above, it turns out that there are still many that have not been studied regarding the problem of price labeling. Therefore, current research needs to be done.

Therefore, based on the background and previous research above, the purpose of this study was to determine the public's perception of the legal aspects of price tagging in Balinese Betutu chicken sales.

\section{THEORETICAL FRAMEWORK}

A label is a part of a product that contains information about the product being marketed which is contained in written or image form. According to Tjiptono (1997:107), label is part of a product that conveys information about the product and the seller. An ordinary label is part of the packaging, or it can also be an tag (identification) attached to the product. In line with Tjiptono's opinion, Swastha (1984:141) also argues that a label is part of an item in the form of information (words) about the item or the seller. Thus, a label may be part of the packaging, or it may be a tag attached directly to an item. According to Marinus (2002:192), there are three types of labels based on their functions, namely: 1) Brand labels are the use of labels that are solely used as brands. 2) Grade label is a label that shows a certain quality level of an item. This label is expressed in writing or in words. 3) Descriptive Label is objective information about the use, construction, maintenance of appearance and other characteristics of the product. Meanwhile, according to Simamora (2000:502), labels are classified into several types, namely: 1) Product labels are part of the packaging of a product that contains information about the product or product sales. 2) The brand label (brand label) is the brand name that is placed on the product packaging. 3) The grade label identifies the quality of the product, this label can consist of letters, numbers or other methods to indicate the quality level of the product itself. 4) Descriptive label (descriptive 
label) describes the content, usage and product characteristics. Labeling is a very important product element that deserves close attention in order to attract consumers. In addition, labeling is influenced by stipulations, namely: a) Unit price (unit princing); states the price per unit of the standard measure. b) Expiration date (open dating); states how long the product is fit for consumption. c) Nutritional labeling (nutritional labeling); states the nutritional value in the product (Kotler, 2000:478).

One of the components contained in a product is price. Price is the value of a product that has an influence on the profits obtained by the producer for the business or product being traded. This price is one that is considered in the buying and selling process. In addition, this price provides more information than a label on the product that contains a number given by the seller. Price is one of the elements of the marketing mix that generates revenue, price is the easiest element in a marketing program to customize, product features, channels, and even communication require more time (Kotler \& Keller, 2009:67). According to Saladin (2003:95), price is an amount of money as a medium of exchange for products or services. From the consumer's point of view, price is often used as an indicator of value when the price is related to the perceived benefits of a good or service. Value as the ratio between the perceived benefits to the price. For products that are useful to customers and anticipate the purchasing power of customers, the company makes various packaging, sizes and types of products. The objectives of pricing (Swastha, 2006:173) include: a) Survival, in favorable market conditions, the objective of pricing may include the level of profitability desired to ensure survival. b) Maximizing profits, setting prices to ensure maximization of profitability within a certain period. The specified period will be related to the service life cycle. c) Maximization of sales, pricing to build market share. This may involve selling at an initial loss in an attempt to seize high market share. d) Prestige (prestige), a service company may wish to use the application of price to place itself exclusively. Swastha (2006:56) finds empirical evidence that reducing prices will increase the threat when prices are raised.

Products are anything that can be offered to the market to get attention, buy, use, or consume and can satisfy wants or needs. If defined broadly, products include physical objects, services, people, places, organizations, and ideas (Abdullah \& Tantri, 2013:153). The definition of a product according to David (2001:3), a product is anything that has value in a target market where kemempuannya provide benefits and satisfaction including objects, services, organizations, places, people, ideas. It can be concluded that a product is a set of attributes both tangible and intangible. Furthermore, Carthy \& Perrefault (2003:107) argues that products are the result of production which will be thrown to consumers to be distributed and utilized by consumers to meet their needs. Meanwhile, according to Saladi (2003:121), a product is anything that can be offered to a market for attention, possession, use or consumption so as to satisfy wants and needs. The product in this research is Balinese Betutu Chicken. Ayam Betutu is a side dish made from whole chicken or duck filled with spices, then grilled in the husk fire. This food is a regional specialty that is very synonymous with Bali. This food is very easy to find in food stalls that specialize in selling betutu chicken is the main menu. Everywhere in Bali sells this food.

Research on price tags has been conducted previously by several researchers, such as: Wijaya \& Rahayu (2014); Oktariyadi (2014); Fadlillah, Nuraida, \& Purnomo (2015); Sari et al. (2019); Pratiwi (2019) and Widyastuti (2019). Wijaya \& Rahayu (2014) in their research compared the level of compliance with the Food Household Industry (IRTP) product label with applicable regulations (RI Law No. 18 of 2012). The results of this study indicate that the three most IRTP products in Bogor City are flour and its processed products $(31 \%)$, processed grains and tubers (13\%), and soft drinks and powdered drinks (10\%). The compliance levels for the technical element group for the labeling of the three types of products were 44,45 , and $73 \%$ respectively, for the group of written elements on the label were 75,80 , and $60 \%$, for the minimum label description element group was 69,64 , and $66 \%$, and for groups of elements not containing information prohibited on the label are 99, 100 , and $96 \%$. The average labeling fulfillment rates of the three types of products were 72 , 72 , and $74 \%$, respectively. The low level of compliance with labeling indicates that further 
guidance is needed for IRTPs, especially regarding labeling criteria in accordance with applicable regulations. Oktariyadi (2014) examines the implementation of food labeling by household-scale food entrepreneurs in Pugeran Village, Gondang District, Mojokerto Regency, and the constraints experienced by household-scale food entrepreneurs in the labeling process of food produced and the efforts made by the Health Office in relation to by labeling food by household-scale food entrepreneurs that are not in accordance with food labeling regulations. The results of his research indicate that the majority of household-scale food businesses do not include complete food labels. This is due to a lack of legal awareness by the business actors concerned. Apart from a lack of legal awareness, the problem in the food labeling process by business actors is due to external factors, namely because it is based on the distributor's request. Meanwhile, the Health Office has never imposed strict sanctions on household-scale food entrepreneurs who do not include complete food label provisions.

Other researchers who studied labeling are Fadlillah, Nuraida, \& Purnomo (2015) with the aim of evaluating consumer concerns about labels and BTP in the city of Bogor. Respondents in this study were divided into two groups, namely the group aged 15-24 years and aged $>24$ years. Respondents who were involved in the survey were 201 people for the 15-24 year group and 150 people for the group> 24 years. The results showed that respondents who always read labels for the 15-24 years and $>24$ years old groups were $33 \%$ and $67 \%$, respectively. Of those who read the labels, $95 \%$ of respondents aged $15-24$ years and $73 \%$ of respondents aged $>24$ years know the term BTP. Statistical analysis using Chi square shows a correlation between education and the habit of reading labels. The same is true of income. The higher the education and income of the respondents, the higher the frequency of reading the labels. A similar study was investigated by Sari et al. (2019) who examined the effect of halal labels and prices on decisions to buy Wardah cosmetic products. The results of this study indicate that the effect of the halal label and price on the decision to buy Wardah cosmetic products has a small effect.

Pratiwi (2019) in her research aims to determine the implementation of labeling and find solutions to obstacles in the implementation of labeling. The results of his research show that many foods from Home Industry Food products (PIRT) do not include ingredients on the packaging label, this is detrimental to consumers of the right to product safety. Business actors do not know the rules regarding labels and do not receive socialization. Pekanbaru City Government needs to supervise the inclusion of ingredients on labels and provide guidance to business actors regarding the implementation of labeling in accordance with the Prevailing Laws. Furthermore, Widyastuti (2019) in his research also reviewed things similar to the current research. Research from Widyastuti (2019) discusses the effect of the halal label, price, and quality on Muslim consumer preferences in purchasing foreign cosmetics. Respondents in this study were 100 Muslim female students in Malang. The results of this study indicate that simultaneously the halal label, price, and quality significantly influence the preferences of Muslim consumers in purchasing foreign cosmetics. Partially, each halal label, price, and quality also significantly influence the preferences of Muslim consumers in purchasing foreign cosmetics.

\section{METHOD}

This type of research used in this research is normative legal research which examines a statutory regulation. This study also used a survey sample (cross sectional study), while the population of this study were housewives in Banjar Anyar, Sumertha Kelod Village, East Denpasar District, Denpasar City, Bali. The number of samples in this study was determined based on the Slovin formula and was collected using systematic random sampling technique. The research variables include: (1) The importance of giving price tags; (2) Without the label violating the law; (3) Act on the sale of goods. Standardized questionnairebased direct interview techniques were used to collect data. The questionnaire that has been completely filled in, before processing (inputing, cleaning, and analyzing), is given a code (coding) first. Data processing is carried out on a computer using the SPSS program. 
Interviewers are four students of Master of Linguistics. After the data is complete, then it is analyzed descriptively.

\section{RESULTS}

\subsection{Level of Understanding the Importance of Price Labeling}

The number of respondents in this study were 103 people. 103 of these respondents were housewives. The level of understanding examined in this study is the importance of price tagging in Balinese Betutu chicken sales. There are three categories in finding the level of understanding of the importance of labeling, namely: very important, important, less important. Based on the interviews and data management carried out, the results can be seen in table 1 below.

Table 1. Level of Understanding of the Importance of Price Labeling

\begin{tabular}{llcc|c|c}
\hline \multicolumn{5}{c}{ IMPORTANT PRICE TAGGING } \\
\hline \multirow{5}{*}{ Valid } & Frequency & Percent & Valid Percent & $\begin{array}{c}\text { Cumulative } \\
\text { Percent }\end{array}$ \\
\cline { 2 - 6 } & VERY IMPORTANT & 32 & 31.1 & 31.1 & 31.1 \\
\cline { 2 - 6 } & $\begin{array}{l}\text { IMPORTANT } \\
\text { NOT TOO }\end{array}$ & 67 & 65.0 & 65.0 & 96.1 \\
\cline { 2 - 6 } & IMPORTANT & 4 & 3.9 & 3.9 & 100.0 \\
\hline & Total & 103 & 100.0 & 100.0 & \\
\hline
\end{tabular}

In table 1 above, it can be seen that the majority (65.0\%) of respondents consider that price tagging is important in selling Balinese Betutu chickens. Furthermore, as many as $31.1 \%$ of respondents thought that the price tagging in selling Balinese Betutu chickens was very important, and only $3.9 \%$ of the 103 respondents considered that the price tagging in selling Balinese Betutu chickens was less important. From the results presented above, it can be concluded that the respondents consider that the price tagging of the betutu chicken is very important.

\subsection{Level of Understanding Without Labels Breaking the Law}

In table 2 below, it is illustrated that as many as $55.3 \%$ of respondents do not know that without a label in selling Balinese Betutu chickens is against the law. Then followed in second from bottom in table 2 that as many as $28.2 \%$ of respondents do not know that without a label in selling Balinese Betutu chickens is against the law. Furthermore, as many as $14.6 \%$ of respondents knew that without a label in selling Balinese Betutu chickens was against the law and only $1.9 \%$ of the total 103 respondents were very aware that without a label on selling Balinese Betutu Chicken was against the law. From the description of the results described above, it can be concluded that most respondents do not know that without a label in selling Balinese Betutu chickens is against the law. This is very concerning because there are still many who do not know that there is a law that regulates the labeling of a product, good or service. It is clear that if a product, goods or services are traded but do not pay attention to the labeling aspect, it may violate the law.

Table 2. Level of Understanding Without Labels Breaking the Law WITHOUT THE LABEL BREAKING THE LAW

\begin{tabular}{clc|c|c|c}
\hline & & Frequency & Percent & Valid Percent & $\begin{array}{c}\text { Cumulative } \\
\text { Percent }\end{array}$ \\
\hline Valid & $\begin{array}{l}\text { VERY } \\
\text { UNDERSTAND }\end{array}$ & 2 & 1.9 & 1.9 & 1.9 \\
\cline { 2 - 6 } & UNDERSTAND & 15 & 14.6 & 14.6 & 16.5 \\
\cline { 2 - 6 } & $\begin{array}{l}\text { NOT REALLY } \\
\text { UNDERSTAND }\end{array}$ & 29 & 28.2 & 28.2 & 44.7 \\
\hline $\begin{array}{l}\text { DO NOT } \\
\text { UNDERSTAND }\end{array}$ & 57 & 55.3 & 55.3 & 100.0 \\
\hline
\end{tabular}




\begin{tabular}{l|c|c|c|}
\hline Total & 103 & 100.0 & 100.0 \\
\hline
\end{tabular}

\subsection{Level of Understanding of the Law on the Sale of Goods}

The results obtained from the respondent's level of understanding of the laws of selling goods. From table 3 below, it can be seen that as many as $77.7 \%$ of respondents do not know about the law on selling goods. Furthermore, as many as $16.5 \%$ of respondents did not know about the laws on selling goods. Meanwhile, $4.9 \%$ of respondents know the laws on the sale of goods and only $1.0 \%$ of respondents know very well about the laws on selling goods. From the description above, it can be concluded that most respondents do not know about the law on selling goods. The law on the sale of goods needs to be understood by both the seller and the buyer because basically all products, goods or services marketed have been regulated by law.

Table 3. Level of Understanding of the Law on Sale of Goods

\begin{tabular}{|c|c|c|c|c|c|}
\hline \multicolumn{6}{|c|}{ LAWS ON SALE OF GOODS } \\
\hline & & Frequency & Percent & Valid Percent & $\begin{array}{c}\text { Cumulative } \\
\text { Percent }\end{array}$ \\
\hline \multirow[t]{5}{*}{$\overline{\text { Valid }}$} & $\begin{array}{l}\text { VERY } \\
\text { UNDERSTAND }\end{array}$ & 1 & 1.0 & 1.0 & 1.0 \\
\hline & UNDERSTAND & 5 & 4.9 & 4.9 & 5.8 \\
\hline & $\begin{array}{l}\text { NOT REALLY } \\
\text { UNDERSTAND }\end{array}$ & 17 & 16.5 & 16.5 & 22.3 \\
\hline & $\begin{array}{l}\text { DO NOT } \\
\text { UNDERSTAND }\end{array}$ & 80 & 77.7 & 77.7 & 100.0 \\
\hline & Total & 103 & 100.0 & 100.0 & \\
\hline
\end{tabular}

\section{DISCUSSION}

The result obtained from the level of public understanding of the legal aspects of price tagging in Balinese Betutu chicken sales is that the average level of understanding is still lacking. At the level of understanding the importance of price tagging, the majority of respondents considered that price tagging was important in the sale of betutu chickens, meanwhile at the level of understanding without labels it was against the law and understanding of the law on selling goods was still lacking. There are still many people who do not know about the legal aspects of labeling, both producers and consumers. From the results described above, the results of this study are in line with the results of research conducted by several researchers, such as Septian \& Rahayu (2014) in a study of 88 IRTP managers in the city of Bogor. This research aims to determine the level of knowledge of the manager of the Home Food Industry (IRTP) and the suitability of food packaging labels. The result obtained is that IRTP knowledge is still lacking, especially knowledge about label definition and label function on food packaging. The results of the correlation analysis showed that there was no significant relationship $(p>0.05)$ between the characteristics of the IRTP manager (age, education level, position, and socioeconomic status) and their perceptions of food packaging labels. The same result was also obtained by Wijaya \& Rahayu (2014) that the level of fulfillment of labeling in the Food Household Industry producers in the city of Bogor is still low. The samples of this research are the most IRTP products in Bogor, namely flour and its processed products; processed grains and tubers; and soft drinks and powder drinks. Furthermore, the current research results are also supported by the results of research from Oktariyadi (2014) that the majority of householdscale food entrepreneurs do not include complete food labels. Then Oktariyadi (2014) adds that the reason is that this is due to a lack of legal awareness by the business actors concerned. Apart from a lack of legal awareness, the problem in the food labeling process by business actors is due to external factors, namely because it is based on the distributor's request.

The results of the current study and several other previous studies show similarities. This is supported by the results of research obtained by Alfian \& Marpaung (2017) that there 
is a significant indirect effect of the halal label variable and brand / brand image on purchasing decisions through price. Fadlillah et al. (2015) also revealed that education and the habit of reading labels have a correlation with consumer concern. The higher the education and income of the respondents, the higher the frequency of reading the labels. Furthermore Arifiana et al. (2013) revealed that the label variable has the strongest influence compared to other variables, so the label variable has a dominant influence on the structure of purchasing decisions.

\section{CONCLUSION}

Based on the results and discussion above, it can be concluded that as many as $65 \%$ of respondents consider the price tagging important in selling Balinese Betutu chickens and only $3.9 \%$ of the 103 respondents think that the price tagging of Balinese Betutu chicken sales is less important. At the level of understanding without a label violating the law, it was allowed as many as $55.3 \%$ of respondents did not know that without a label in selling Balinese betutu chickens was against the law and only $1.9 \%$ of the total 103 respondents were very aware that without a label on selling Balinese Betutu chickens was against the law. Meanwhile, at the level of understanding of the laws on sale of goods, it was found that as many as $77.7 \%$ of respondents did not know about the laws on selling goods and only $1.0 \%$ of respondents knew very well about the laws on selling goods. Based on these results, this is of course very worrying because there are still many people who are not aware of the law that regulates the labeling of a business product. For this reason, there is a need for counseling or education about labeling from related parties to be known to both producers and consumers because these two parties share an attachment in the process of buying and selling.

\section{REFERENCES}

Abdullah, T., \& Tantri, F. (2013). Manajemen Pemasaran (II). Jakarta: PT Raja Grafindo Persada.

Alfian, I., \& Marpaung, M. (2017). Analisis Pengaruh Label Halal, Brand dan Harga terhadap Keputusan Pembelian di Kota Medan. AT-TAWASSUTH: Jurnal Ekonomi Islam, 2(1), 118-141.

Arifiana, W. E., Kumadji, S., \& Fanani, D. (2013). Pengaruh atribut produk terhadap keputusan pembelian (Survei pada ibu rumah tangga perumahan Bumi Asri Sengkaling RW 05 Desa Mulyoagung Kecamatan Dau Kabupaten Malang pembeli deterjen Rinso). Jurnal Administrasi Bisnis, 1(2), 231-240.

Carthy, M., \& Perrefault. (2003). Dasar-Dasar Pemasaran. Jakarta: Erlangga.

David, G. (2001). Managing Quality. Jakarta: Ghalia Indonesia.

Devi, V. C., Sartono, A., \& Isworo, J. T. (2013). Praktek Pemilihan Makanan Kemasan Berdasarkan Tingkat Pengetahuan Tentang Label Produk Makanan Kemasan, Jenis Kelamin, dan Usia Konsumen di Pasar Swalayan ADA Setiabudi Semarang. Jurnal Gizi: Universitas Muhammadiyah Semarang, 2(2).

Elisabeth, D. A. A. (2017). Pengaruh Pengemasan dan Pelabelan pada Penerimaan Mi Kering Berbahan Baku Tepung Komposit Ubijalar dan Keladi. Jurnal Matematika Sains Dan Teknologi, 18(2), 111-119.

Fadlillah, H. N., Nuraida, L., \& Purnomo, E. H. (2015). Kepedulian Konsumen terhadap Label dan Informasi Bahan Tambahan Pangan (BTP) pada Label Kemasan Pangan di Kota Bogor. Jurnal Mutu Pangan: Indonesian Journal of Food Quality, 2(2), 119-126.

Iskandar, Y. D. (2015). Perlindungan Hukum Konsumen dalam Hal Pencantuman Produk Halal oleh Pelaku Usaha (Studi pada Produsen Pangan dalam Kemasan di Kota Pontianak). Jurnal Nestor Magister Hukum, 2(2).

Kotler, \& Keller. (2009). Manajemen Pemasaran (13th ed.). Jakarta: Erlangga.

Kotler, P. (2000). Manajemen Pemasaran (Jilid 2). Jakarta: Prenhallindo.

Kristiyanti, C. T. S. (2008). Hukum Perlindungan Konsumen. Jakarta: Sinar Grafika.

Maharani, A. A. S. A. S., \& Markeling, I. K. (2018). Akibat Hukum terhadap Perbedaan Harga Barang pada Label (Price Tag) dan Harga Kasir. Kertha Semaya: Journal IImu Hukum, 2(5), 1-15.

Marinus, A. (2002). Dasar-Dasar Pemasaran. Jakarta: Raja Grafindo Persada.

Nugraha, D. W. (2014). Sistem Informasi Penjualan Makanan Khas Kota Palu Berbasis Web. Jurnal Teknik Informatika, 7(2).

Oktariyadi, D. (2014). Implementasi Peraturan Pelabelan Pangan pada Industri Rumah Tangga Pangan di Desa Pugeran Kecamatan Gondang Kabupaten Mojokerto. Novum: Jurnal Hukum, 
$1(1), 118-128$.

Pratiwi, R. (2019). Pencantuman Komposisi Bahan pada Label Makanan Kemasan sebagai Hak Hukum di Kota Pekanbaru. Jurnal Gagasan Hukum, 1(1).

Puasa, S. N. (2017). Penerapan Hukum terhadap Label dan Iklan Pangan Menurut Undang-undang Nomor 18 Tahun 2012 tentang Pangan. Lex Privatum, 5(9).

Rosidi, A., Musdianingwati, T., Suyanto, A., Yusuf, M., \& Sulistyowati, E. (2018). Pengetahuan dan Sikap Mahasiswa dalam Keputusan Pembelian Produk Halal. Jurnal Gizi: Universitas Muhammadiyah Semarang, 7(2).

Saladin, D. (2003). Manajemen Pemasaran. Bandung: Linda Karya.

Sari, F. M., Makhrian, A., \& Buldani, K. (2019). Pengaruh Label Halal dan Harga terhadap Keputusan Membeli Produk Kosmetik Wardah (Studi Pada Mahasiswi Prodi Manajemen Universitas Bengkulu). Profesional: Jurnal Komunikasi Dan Administrasi Publik, 5(1).

Septian, J., \& Rahayu, W. P. (2014). Pengetahuan Pelabelan Produsen Industri Rumah Tangga Pangan di Kota Bogor. Jurnal Mutu Pangan (Indonesian Journal of Food Quality), 1(2), 145150.

Simamora, H. (2000). Manajemen Pemasaran Internasional. Jakarta: Salemba Empat.

Swastha, B. (1984). Azas-Azas Marketing. Yogyakarta: Liberty.

Swastha, B. D. (2006). Manajemen Penjualan. Yogyakarta: BPFE.

Tjiptono, F. (1997). Strategi Pemasaran. Yogyakarta: Andi.

Widyastuti, L. (2019). Pengaruh Label Halal, Harga, dan Kualitas terhadap Preferensi Konsumen Muslim dalam Pembelian Kosmetik Asing (Studi pada Mahasiswi Muslim di Kota Malang). Jurnal IImuah Mahasiswa FEB Universitas Brawijaya, 7(2).

Wijaya, W. A., \& Rahayu, W. P. (2014). Pengetahuan Pelabelan Produsen Industri Rumah Tangga Pangan di Kota Bogor. Jurnal Mutu Pangan: Indonesian Journal of Food Quality, 1(1), 65-73. 